\title{
Determination of Nitrate and Nitrite Content of Dietary Supplements Using Ion Chromatography
}

\author{
Iltaf Shah, Andrea Petroczi, Ricky A James and Declan P Naughton*
}

School of Life Sciences, Kingston University, UK

\begin{abstract}
Following the discovery of nitrite and nitrate as pro-drugs of the vasorelaxant nitric oxide, many studies have reported enhanced athletic performance following intake of these ions either intravenously or as a food supplement. The primary aim of this study was to develop a new accurate, reliable and robust ion chromatography based method. The newly developed method was applied to selected foodstuffs in powdered and/or juice form to measure levels of nitrate and nitrite. In addition to the commonly used beetroot juice, an initial HPLC-based screen of a range of foods identified spinach powder with very high nitrate and nitrite content. As a result of the initial screening, branded beetroot juice, concentrated beetroot juice and spinach powder were analysed using a new extraction method followed by a newly developed and validated ion chromatographic determination of nitrate and nitrite levels. The new ion chromatography based assay showed higher efficiency and better recovery than the HPLC approach. Significant inter-batch variations were found in levels of nitrate and nitrite in the beetroot juice and concentrated beetroot juice samples tested. In contrast spinach powder could provide a homogenous source of nitrate and nitrate for physiological studies. In summary, the new assay is rapid and efficient facilitating rigorous analyses of nitrate and nitrite levels prior to investigations requiring intake of foodstuffs containing these nitric oxide precursors.
\end{abstract}

Keywords: Ion chromatography; Beetroot juice; Nitrate; Nitrite; Spinach powder

\section{Introduction}

Nitrate, a compound of low toxicity, when ingested orally, is absorbed from the gastrointestinal tract in its free form. About $20-28 \%$ of this is then secreted into saliva and only $4-8 \%$ of the ingested nitrate is converted into nitrite by nitrate reducing bacteria. The resulting nitrite is then further reduced to nitric oxide by the same bacteria [1-3]. Many studies have related the beneficial effect of nitrate, nitrite and nitric oxide consumption to cardiovascular health, glucose and calcium regulation, muscle contractility $[4,5]$, mitochondrial bio-synthesis and respiration [6-12], and regulation of blood flow [6,13-15]. Hemodynamic effects [16-18] in the form of increasing exercise performance and as an energy booster have also been reported $[5,19,20]$. The role of bioactive nitric oxide has recently being evaluated in the form of single dosage [6] or chronic use $[21,22]$. Its use is independent from the factors such as health status, age and fitness $[23,24]$.

While nitrate is nontoxic even in higher doses, nitrite can cause serious harm at lower levels. Nitrites are known to cause methemoglobinemia in infants and cancer and hypotension in adults $[1-3,25,26]$ and therefore its consumption is restricted $[27,28]$. Nitrate in the human diet is present mainly in beetroots and most of the leafy green vegetables like spinach and lettuce [29]. Many studies have revealed the effects of nitrates on the human body by its direct consumption in the form of nitrate-rich dietary supplements mainly, beetroot juice (BJ) or inorganic nitrates [19,28,30-35]. The use of inorganic nitrates are associated with several problems and it is not an ideal supplementation option [17,26,36-38]. A cycling time trial performance study based on nitrate rich BJ supplementation [21], and other studies of nitrate supplementation [5,19], explained the effect of nitrate [nitrite and nitric oxide] on increased Power Output (PO) and enhanced time trial (TT) performance [5,19,20,39-44]. Due to the limitations of exercise capacity tests [45] time trial (TT) tests were performed involving subjects completing a given distance in the fastest possible time $[46,47]$
Spinach powder (SP) has not been given due consideration as a supplementation choice in the past. It is one of the more potent alkaline vegetable, having large quantities of nitrates along with other dietary preferences [48]. Among other methods, ion chromatography is one of the favourite techniques for accurate analyses of nitrate and nitrites [7,8,34,49-53]. However, to date extraction and ion chromatographic methods applied to beetroot juices and spinach have not been reported without the use of ion pair reagents [54]. To assist physiological studies, a new accurate, reliable and robust ion chromatography method was developed and applied to selected foodstuffs in powdered and/or juice form based on screening results of levels of nitrate and nitrite in a wider range of foodstuffs.

\section{Experimental}

\section{Sample collection}

For the initial screening phase carrot, beetroot, celery, tomato and SP's along with black radish, celery and BJ's were acquired from local health shops or mail order suppliers. For the analyses of the selected foodstuffs, a total of 10 branded BJ samples and a further 12 concentrated beetroot juice (CBJ) samples were purchased from different stores across London. A total of nine SP samples (50 g each) belonging to nine different batches were tested. The BJ samples were collected with an expiry ranging from Nov-2011 to Jul-2012 representing 10 batches, CBJ samples having an expiry ranging between Jun-2011 to Jul-2012

*Corresponding author: Declan P Naughton, Faculty of Science, Engineering and Computing, Penrhyn Road, Kingston upon Thames, Surrey KT1 2EE, UK, Tel: 02084177097; E-mail: D.Naughton@kingston.ac.uk

Received December 04, 2013; Accepted December 26, 2013; Published December 30, 2013

Citation: Shah I, Petroczi A, James RA, Naughton DP (2013) Determination of Nitrate and Nitrite Content of Dietary Supplements Using lon Chromatography. J Anal Bioanal Tech S12: 003. doi:10.4172/2155-9872.S12-003

Copyright: @ 2013 Shah I, et al. This is an open-access article distributed under the terms of the Creative Commons Attribution License, which permits unrestricted use, distribution, and reproduction in any medium, provided the original author and source are credited. 
representing 12 batches and SP have an expiry range of Dec-2011 to July-2012.

\section{Reagents, chemicals and consumables}

Sodium nitrate, sodium nitrite, sodium iodide, oxalate, sodium bromide, sodium hydroxide, sodium carbonate, sodium bicarbonate and chloroform were obtained from Sigma-Aldrich UK. Deionised water of $15 \mathrm{M} \Omega$-cm quality was obtained in-house from ELGA-DV25 water purifier, Marlow UK. Millex-HA syringe driven filters $(0.45$ $\mu \mathrm{m} \times 33 \mathrm{~mm}$ ) were purchased from, Millipore Ltd. Ireland.

\section{Instrumentation}

An anion exchange ion chromatography column IonPac AS14A $(4 \times 250 \mathrm{~mm} \times 7 \mu \mathrm{m})$, having a $100 \AA$ pore size was used for analysis together with IonPac AS14A $(4 \times 50 \mathrm{~mm})$ guard column, both columns were obtained from Dionex UK Ltd. The ion chromatography column was installed onto a PerkinElmer 225 series HPLC system comprising of 225 series EP Diode Array Detector, a pump and an autosampler, PerkinElmer Cambridge, UK. pH measurements were determined using SevenEasy $\mathrm{pH}$ meter Mettler Toledo, having a combined glass electrode, Leicester, UK. Ultrasonic water bath used was Sonorex digital supplied by Monmouth Scientific Somerset, UK.

\section{Screening of vegetables for nitrate and nitrite content}

The HPLC based method of Tamme et al. [52] was modified for screening investigations. A total of five vegetable powders and two vegetable juices were collected for analysis. Prior to analysis, the powders and juices were stored at $4^{\circ} \mathrm{C}$. To prepare the vegetable powders for analysis $1 \mathrm{~g}$ was weighed into a flask and deionised water $(20 \mathrm{~mL})$ was added followed by mixing. Then activated charcoal $(0.1 \mathrm{~g})$ was added followed by mixing. The flask was then agitated in water bath at $60^{\circ} \mathrm{C}$ for $20 \mathrm{~min}$ before being allowed to cool down to room temperature. The mixture was spun at $12,300 \times \mathrm{g}$ for $10 \mathrm{~min}$. The supernatant was collected and filtered through a $0.45 \mu \mathrm{m}$ membrane. The prepared sample was immediately analysed. It was necessary to further dilute spinach and beetroot samples in order to determine nitrate. $20 \mu \mathrm{L}$ of the above supernatant was added to $980 \mu \mathrm{L}$ of deionised water before filtration and analysis.

To prepare the vegetable juices for analysis, $15 \mathrm{~g}$ of juice was weighed into a flask. Deionised water $(20 \mathrm{~mL})$ was added followed by mixing. To clarify $5 \mathrm{~mL}$ Carrez-I solution (3.60 g potassium hexacyanoferrate (II) trihydrate made up to $100 \mathrm{~mL}$ with water) was added and mixed. 5 mL Carrez-II solution (7.20 g zinc sulfate heptahydrate made up to 100 $\mathrm{mL}$ with water) was added followed by mixing. Protein precipitation occurred and the suspension was spun for $20 \mathrm{~min}$ at $2000 \times \mathrm{g}$. The supernatant was collected and made up to $100 \mathrm{~mL}$ with deionised water before filtration through a $0.45 \mu \mathrm{m}$ membrane, followed by immediate analysis. For beetroot and black radish juices this process was repeated but with dilution to $1000 \mathrm{~mL}$ and $500 \mathrm{~mL}$ respectively. The $100 \mathrm{~mL}$ dilutions were used to determine nitrite (and also nitrate in celery juice) and the $1000 \mathrm{~mL}$ and $500 \mathrm{~mL}$ dilutions were made for determining nitrate in beetroot and black radish juices respectively.

\section{Sample preparation for ion chromatography analysis}

One gram of SP was weighed. The SP was dissolved in $50 \mathrm{~mL}$ deionised water in a volumetric flask, which was free from any nitrates. The flask was then placed in a boiling water bath at $80^{\circ} \mathrm{C}$ for 20 minutes and shaken up well. The flask was left to cool. The spinach solution was diluted further with $50 \mathrm{~mL}$ deionised water. The dissolved SP was further filtered through $0.45 \mu \mathrm{m}$ syringe filter. The first filtrate of 3
$\mathrm{mL}$ was discarded and the following filtrate of $1 \mathrm{~mL}$ was collected for determination of nitrate and nitrite. The samples were further diluted 10 times to fit on the standard curve.

All samples of beetroot juice were stored in the refrigerator at $4^{\circ} \mathrm{C}$ in the dark. First the BJs and CBJ sealed containers were opened, extracted, analysed and stored in the refrigerator at $4^{\circ} \mathrm{C}$ in the dark for further analysis. For analyses, the beetroot juices were shaken well in the ultrasonic bath for 20 minutes at room temperature then the BJ and CBJ samples were diluted with deionised water to fit the standard curve. The diluted samples were filtered through a $0.45 \mu \mathrm{m}$ syringe driven filters. The first $4 \mathrm{~mL}$ collected filtrate was discarded and the following filtrate of $1 \mathrm{~mL}$ was collected for determination of nitrite and nitrate. All samples were analysed immediately after filtration.

The freshly opened BJ and CBJ samples were found to have a $\mathrm{pH}$ of 4.23 . First the samples were analysed for nitrate and nitrite determination at this $\mathrm{pH}$. The extraction methods were adopted from Akyüz et al. [53]. The Mettler Toledo Seven Easy pH meter was calibrated with buffers at $\mathrm{pH}(4,7$ and 9) before using it to record $\mathrm{pH}$ of the beetroot samples. The BJ, CBJ and SP samples were analysed in duplicate and the average value was reported.

\section{Ion chromatography procedure}

Mobile phase was $\left(8 \mathrm{mM} \mathrm{Na}_{2} \mathrm{CO}_{3} / 1 \mathrm{mM} \mathrm{NaHCO}\right.$ ) prepared by mixing $16 \mathrm{~mL}$ of $1 \mathrm{M} \mathrm{Na}_{2} \mathrm{CO}_{3}$ with $2 \mathrm{~mL}$ of $1 \mathrm{M} \mathrm{NaHCO}_{3}$ and diluted to 2 litres in deionised water. Sodium iodide was used as internal standard. Stock solutions of nitrate, nitrite and iodide (internal standard) were prepared by dissolving $10 \mathrm{mg}$ of sodium salts of nitrate, nitrite and iodide each in $10 \mathrm{ml}$ of deionised water. A pellet of $\mathrm{NaOH}$ and 20 drops of chloroform was added to prevent the liberation of nitrous acid and to preserve the analytes [49]. Working solutions of $1 \mathrm{mg} / \mathrm{mL}$ were serially diluted to contain $100,50,25,12,6,3,1.5,0.7,0.3,0.1,0.05,0.02$, and $0.01 \mu \mathrm{g} / \mathrm{mL}$ of nitrate and nitrite. All the solutions were stored at $4^{\circ} \mathrm{C}$.

At the start of the run, the mobile phase was passed through an ion chromatography column until a stable baseline signal was obtained. The optimal anionic exchange mobile phase conditions were obtained through extensive trials by mixing different molarities of $\mathrm{Na}_{2} \mathrm{CO}_{3} /$ $\mathrm{NaHCO}_{3}$. Different flow rates of mobile phases were also tried (range 0.5 to 2 ) together with different injection volumes (range 5-100 $\mu \mathrm{L}$ ). $1.5 \mathrm{~mL} / \mathrm{min}$ flow rate and $50 \mu \mathrm{L}$ injection volume gave best resolution and better peak shape. The best-run time was found to be 15 minutes. The retention times of nitrates and nitrites were $6.7 \pm 0.02$ and 3.4 \pm 0.02 minutes respectively. The flow rate was $1.5 \mathrm{~mL} / \mathrm{min}$ and the wavelength of the diode array detector (DAD) was set to $210 \mathrm{~nm}$ for detection. The injection volume was $50 \mu \mathrm{L}$ and the column temperature was kept at $30^{\circ} \mathrm{C}$. A blank sample was run on regular intervals- mostly after every 5 samples to check for carry over effect. The amounts of nitrites and nitrates in beetroot unknowns were determined by using linear regression equations of the standard curves. The test solutions were diluted accordingly to fit the range set by the standard curves. For the selection of internal standard sodium oxalate, sodium bromide and sodium iodide were tried and sodium iodide was found to be the optimum internal standard having a relatively appropriate and robust retention time. Precision and accuracy tests were carried out by analysing quality controls high, medium and low on the same day in triplicate i.e.; within 24 hours (intra-day) and then within successive days with at least 24 hours interval (inter-day). Recovery tests were evaluated by spiking known concentrations of nitrate and nitrite into beetroot samples and each concentration spiked was analysed in triplicate. Samples were spiked by addition and agitation at known 
Citation: Shah I, Petroczi A, James RA, Naughton DP (2013) Determination of Nitrate and Nitrite Content of Dietary Supplements Using lon Chromatography. J Anal Bioanal Tech S12: 003. doi:10.4172/2155-9872.S12-003

Page 3 of 7

concentrations of $12.5 \mu \mathrm{g} / \mathrm{mL}, 25 \mu \mathrm{g} / \mathrm{mL}$ and $100 \mu \mathrm{g} / \mathrm{mL}$ for QCs at low, medium and high levels. A blank test was also carried out to calculate average recoveries. The lower limit of detection for the assay was defined as the concentration of the standard solution of which the average peak height/peak noise level was 3 .

\section{Statistical analysis}

Data were represented as mean \pm standard deviation of three replicates. Statistical analysis was performed using SPSS 19 software. For BJ and CBJ, one sample $t$-test was used for comparing measured levels of nitrate to the level indicated on the label.

\section{Screening results for nitrate/nitrite levels in foodstuffs}

The content of nitrate and nitrite across a range of candidate supplements varied considerably in the HPLC-based screening study with the nitrate at much higher levels (Table 1). Spinach had the highest levels of nitrate by a considerable margin, followed by beetroot powder. For nitrites, the levels were much lower with beetroot and spinach having the highest of the foodstuffs tested. From this screening stage which was in line with previous findings [7], it was decided to focus on the beetroot and spinach as candidate for supplements based studies of nitrate/nitrite. From these initial screening results, further analyses were warranted for the frequently used beetroot juices in contrast to the highest alternative foodstuff, powdered spinach.

\section{Method Validation for Nitrate and Nitrite in BJ, CBJ and SP}

The method for determination of nitrate and nitrite was validated taking into account the recovery, linearity, sensitivity, reproducibility and influence of the mobile phase solution and interference of the sampling substances. All the solutions, standards and quality controls were prepared in deionised water. The results showed that the standard curve was linear over the range 0.05 to $100 \mu \mathrm{g} / \mathrm{mL}$ for nitrate and nitrite. Figure 1 shows the chromatographic peaks for nitrate and nitrite in $\mathrm{BJ}$, $\mathrm{CBJ}$ and SP.

The lower limit of detection was $10 \mathrm{ng} / \mathrm{mL}$ for nitrate and $15 \mathrm{ng} / \mathrm{mL}$ for nitrite. The intra-day/inter-day precision for the triplicate analyses were determined by calculating the coefficient of variations. Intra-day precision was calculated by running the assay quality controls at three different time intervals within the same day while inter-day precision was calculated by analysing quality controls three times within successive eight days as shown in Table 2.

The recoveries are calculated as an average of the triplicate analysis and are shown in Table 3. The recoveries of nitrate and nitrite were calculated by spiking known amounts of quality controls $(1.5,12.5$, 25 and $100 \mu \mathrm{g} / \mathrm{mL}$ ) into BJ and CBJ samples. As shown in Table 3, the recoveries of nitrates in $\mathrm{BJ}$ and $\mathrm{CBJ}$ samples were in the range of 97.8-103.5\% and $97.2-99.9 \%$, respectively while the average recoveries

\begin{tabular}{|c|c|c|}
\hline Sample & Nitrite Content ${ }^{*}(\mu \mathrm{g} / \mathrm{g})$ & Nitrate Content ${ }^{*}(\mu \mathrm{g} / \mathrm{g})$ \\
\hline Carrot Powder & ** & $620.89 \pm 0.10$ \\
\hline Beetroot Powder & $79.04 \pm 0.22$ & $16478.07 \pm 0.19$ \\
\hline Celery Powder & $10.94 \pm 25.57$ & $716.72 \pm 0.04$ \\
\hline Tomato Powder & $26.63 \pm 0.66$ & $113.41 \pm 0.62$ \\
\hline Spinach Powder & $41.69 \pm 4.99$ & $28867.49 \pm 0.19$ \\
\hline Black Radish Juice & ** & $799.02 \pm 0.69$ \\
\hline Celery Juice & ** & $255.64 \pm 0.15$ \\
\hline Beetroot Juice & $38.00 \pm 3.04$ & $476.27 \pm 0.49$ \\
\hline
\end{tabular}

*Mean of 3 Replicates

**Unresolved peak

Table 1: Levels of nitrate and nitrite in selected food stuffs.

\begin{tabular}{|c|c|c|c|c|c|c|}
\hline \multirow{2}{*}{$\begin{array}{c}\text { Analytes in } \\
(\mu \mathrm{g} / \mathrm{mL})\end{array}$} & \multirow{2}{*}{$\begin{array}{c}\text { Conctrn. } \\
\text { QC's }\end{array}$} & \multirow[b]{2}{*}{$\mathbf{r}^{2}$} & \multicolumn{2}{|c|}{ Intra-day } & \multicolumn{2}{|c|}{ Inter-day } \\
\hline & & & $\begin{array}{c}\text { Precision } \\
\% \text { CV }\end{array}$ & $\begin{array}{c}\text { Accuracy } \\
\%\end{array}$ & $\begin{array}{c}\text { Precision } \\
\% \text { CV }\end{array}$ & $\begin{array}{c}\text { Accuracy } \\
\%\end{array}$ \\
\hline \multirow{3}{*}{ Nitrates in BJ } & 12.5 & \multirow{3}{*}{0.9998} & 0.27 & 102.1 & 1.25 & 88.7 \\
\hline & 25 & & 0.16 & 105.3 & 1.47 & 87.4 \\
\hline & 100 & & 0.17 & 99.5 & 1.48 & 95.2 \\
\hline \multirow{3}{*}{ Nitrites in BJ } & 12.5 & \multirow{3}{*}{0.9998} & 6.9 & 95.2 & 9.33 & 95.2 \\
\hline & 25 & & 12.6 & 93.5 & 11.2 & 95.6 \\
\hline & 100 & & 9.5 & 89.4 & 8.7 & 88.4 \\
\hline \multirow{3}{*}{ Nitrates in CBJ } & 12.5 & \multirow{3}{*}{0.9989} & 6.1 & 96.9 & 8.4 & 97.8 \\
\hline & 25 & & 3.9 & 97.3 & 4.7 & 98.8 \\
\hline & 100 & & 2.4 & 99.1 & 3.7 & 97.8 \\
\hline \multirow{3}{*}{ Nitrites in CBJ } & 12.5 & \multirow{3}{*}{0.9988} & 4.8 & 99.8 & 4.6 & 88.7 \\
\hline & 25 & & 3.7 & 99.9 & 4.8 & 97.9 \\
\hline & 100 & & 3.3 & 88.7 & 7.8 & 88.3 \\
\hline \multirow{3}{*}{ Nitrates in SP } & 12.5 & \multirow{3}{*}{0.9997} & 5.2 & 99.2 & 5.6 & 89.3 \\
\hline & 25 & & 3.2 & 99.6 & 3.4 & 97.3 \\
\hline & 100 & & 3.6 & 99.7 & 2.6 & 98.9 \\
\hline \multirow{3}{*}{ Nitrites in SP } & 12.5 & \multirow{3}{*}{0.9998} & 3.2 & 98.9 & 5.2 & 99.8 \\
\hline & 25 & & 4.4 & 97.4 & 6.3 & 98.9 \\
\hline & 100 & & 3.9 & 99.9 & 4.3 & 97.8 \\
\hline
\end{tabular}

Table 2: Intra-day/inter-day precision, accuracy and linearity $(n=6)$.

\begin{tabular}{|l|c|c|c|c|c|c|}
\hline \multirow{2}{*}{$\begin{array}{l}\text { Spike } \\
\text { levels } \\
\text { In }(\boldsymbol{\mu g} / \mathbf{m L})\end{array}$} & \multicolumn{4}{|c|}{ Recovery (\%) and Coefficient of variation (\%) } \\
\cline { 2 - 7 } & Nitrite & Nitrate & Nitrite & Nitrate & Nitrite & Nitrate \\
\hline 0.05 & $98.8 \pm 1.2$ & $99.1 \pm 1.2$ & $98.1 \pm 1.3$ & $97.9 \pm 1.4$ & $99.7 \pm 1.3$ & $99.9 \pm 1.4$ \\
\hline 1.5 & $99.6 \pm 1.6$ & $97.8 \pm 0.2$ & $96.4 \pm 0.4$ & $97.2 \pm 1.1$ & $99.8 \pm 0.4$ & $99.7 \pm 1.1$ \\
\hline 12.5 & $98.9 \pm 0.2$ & $103.5 \pm 1.1$ & $101.3 \pm 0.7$ & $96.2 \pm 1.3$ & $101.3 \pm 0.7$ & $99.7 \pm 1.3$ \\
\hline 25 & $104.5 \pm 0.4$ & $99.8 \pm 0.3$ & $99.7 \pm 0.8$ & $99.9 \pm 0.9$ & $99.7 \pm 0.8$ & $99.9 \pm 0.9$ \\
\hline 100 & $103.4 \pm 0.9$ & $98.6 \pm 0.5$ & $103.2 \pm 0.9$ & $98.7 \pm 1.2$ & $103.2 \pm 0.9$ & $99.7 \pm 1.2$ \\
\hline
\end{tabular}

Table 3: Recoveries of nitrate and nitrite in BJ, CBJ and SP.

\begin{tabular}{|c|c|c|c|c|c|}
\hline \multirow[t]{2}{*}{$\begin{array}{l}\text { Analytes in } \\
(\mu \mathrm{g} / \mathrm{mL})\end{array}$} & Conctrn. & $\begin{array}{c}1^{\text {st }} \text { Freeze/ } \\
\text { Thaw cycle } \\
(24 \text { hrs }) n=6\end{array}$ & $\begin{array}{c}2^{\text {nd }} \text { Freezel } \\
\text { Thaw } \\
\text { cycle }(48 \text { hrs })\end{array}$ & $\begin{array}{c}3^{\text {rd }} \text { Freezel } \\
\text { Thaw cycle } \\
\text { (72 hrs) }\end{array}$ & \multirow{2}{*}{$\begin{array}{l}\text { \% Change } \\
\text { in Accuracy } \\
\text { after three } \\
\text { F/T Cycles }\end{array}$} \\
\hline & QC's & $\%$ Accuracy & $\%$ Accuracy & $\%$ Accuracy & \\
\hline \multirow{3}{*}{$\begin{array}{l}\text { Nitrates } \\
\text { in BJ }\end{array}$} & 12.5 & 102.6 & 99.18 & 98.78 & -3.72 \\
\hline & 25 & 115.08 & 94.29 & 102.42 & -11 \\
\hline & 100 & 112.5 & 98.94 & 99.45 & -11.6 \\
\hline \multirow{3}{*}{$\begin{array}{l}\text { Nitrites in } \\
\text { BJ }\end{array}$} & 12.5 & 112.2 & 101.1 & 99.11 & -11.67 \\
\hline & 25 & 99.29 & 98.13 & 95.21 & -4.11 \\
\hline & 100 & 99.12 & 98.12 & 98.22 & -0.91 \\
\hline \multirow{3}{*}{$\begin{array}{l}\text { Nitrates in } \\
\text { CBJ }\end{array}$} & 12.5 & 96.23 & 98.25 & 95.36 & -0.9 \\
\hline & 25 & 84.5 & 95.46 & 82.33 & -2.57 \\
\hline & 100 & 88.12 & 90.17 & 82.13 & -6.8 \\
\hline \multirow{3}{*}{$\begin{array}{l}\text { Nitrites in } \\
\text { CBJ }\end{array}$} & 12.5 & 90.23 & 89.38 & 90.27 & 0.04 \\
\hline & 25 & 103.38 & 87.33 & 80.04 & -22.57 \\
\hline & 100 & 100.23 & 113.5 & 99.5 & -0.73 \\
\hline \multirow{3}{*}{$\begin{array}{l}\text { Nitrates in } \\
\text { SP }\end{array}$} & 12.5 & 111.21 & 101.6 & 112.2 & 0.89 \\
\hline & 25 & 112.51 & 94.58 & 96.33 & -14.38 \\
\hline & 100 & 112.23 & 102.5 & 99.59 & -11.26 \\
\hline \multirow{3}{*}{$\begin{array}{l}\text { Nitrites in } \\
\text { SP }\end{array}$} & 12.5 & 99.26 & 100.2 & 98.6 & -0.66 \\
\hline & 25 & 100 & 96.25 & 88.75 & -11.25 \\
\hline & 100 & 104.5 & 99.85 & 99.58 & -4.71 \\
\hline
\end{tabular}

Table 4: Stability results for nitrates-nitrites containing food stuffs during freezethaw cycles.

were 99.9 and $98.7 \%$ respectively. Moreover, the recoveries of nitrite in BJ and CBJ were $98.9-104.5 \%$ and $96.4-103.2 \%$, respectively and the average recoveries were 99.9 and $99.5 \%$, respectively.

Three freeze and thaw cycles were conducted at 24 hours, 48 


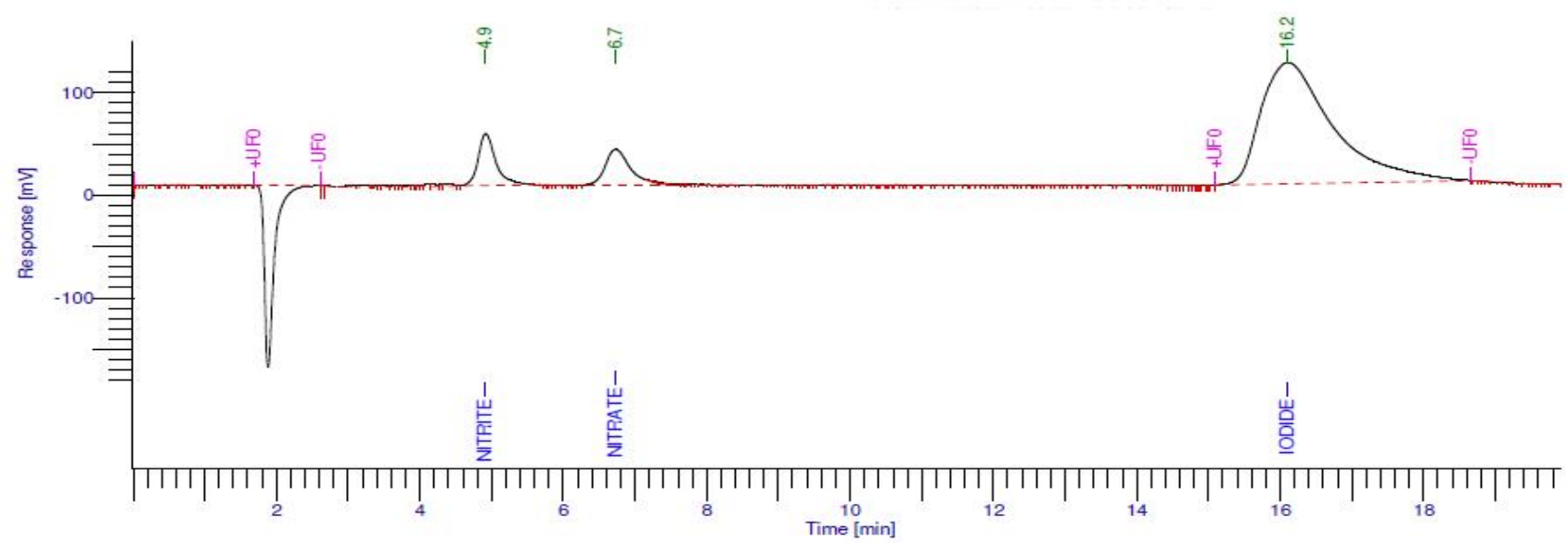

Figure 1a: Nitrate and Nitrite in BJ sample

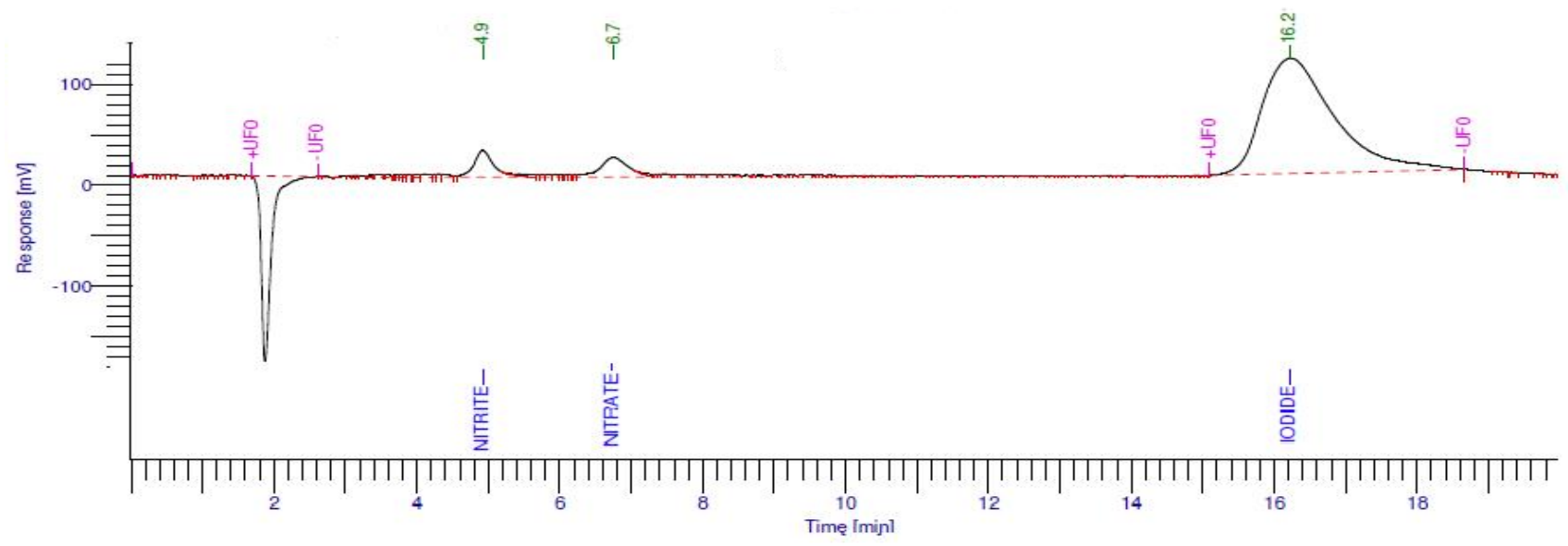

Figure 1b: Nitrate and Nitrite in CBJ sample

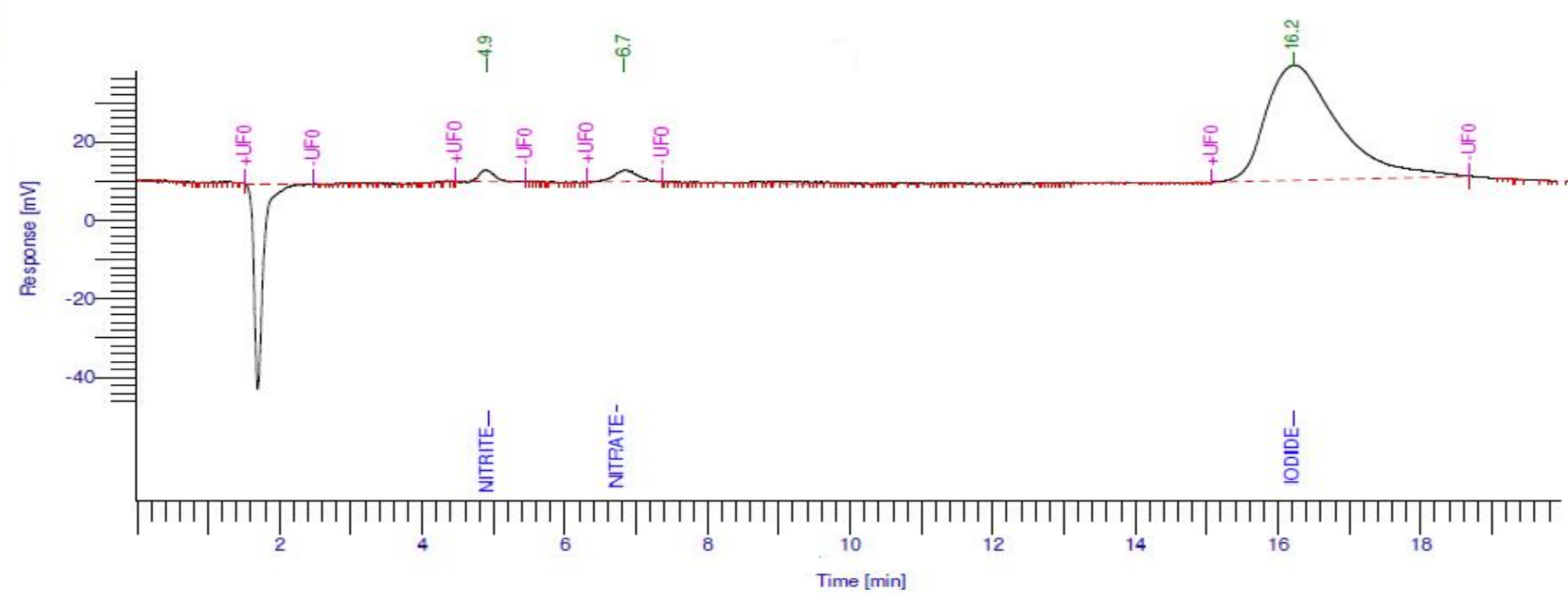

Figure 1c: Nitrate and Nitrite in SP sample

Figure 1: Ion chromatogram of nitrate and nitrite in BJ, CBJ and SP samples. For analysis the SP solution was diluted to 1 in a 1000. 


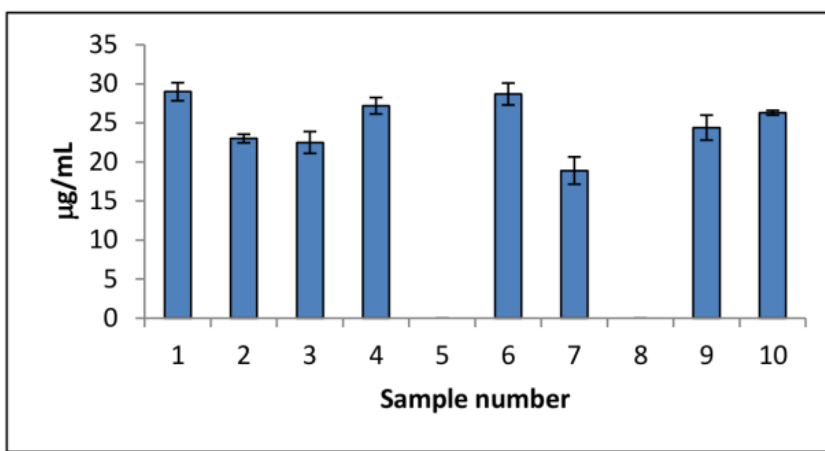

Figure 2a: Nitrite in BJ

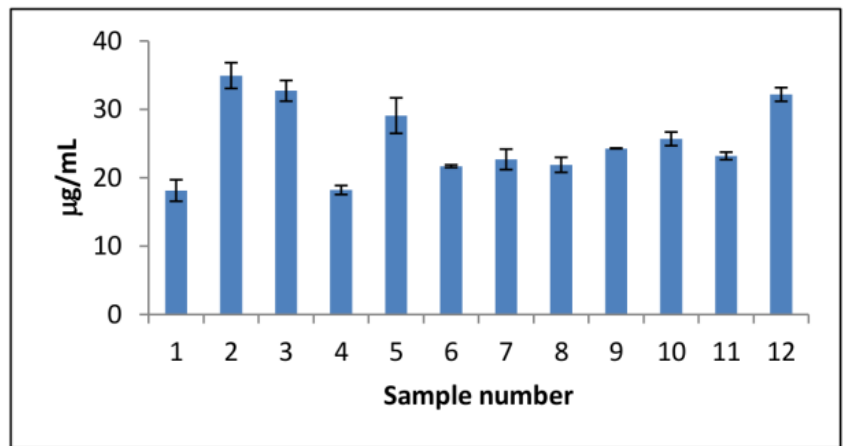

Figure 2b: Nitrite in $\mathrm{CBJ}$

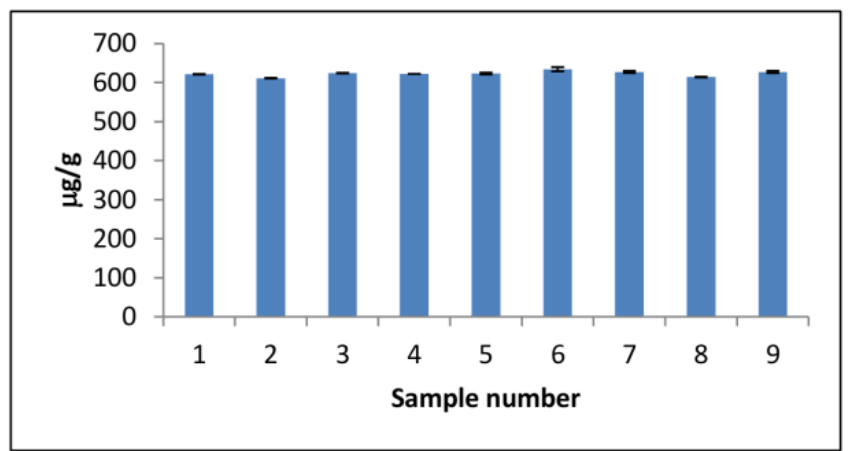

Figure 2c: Nitrite in SP

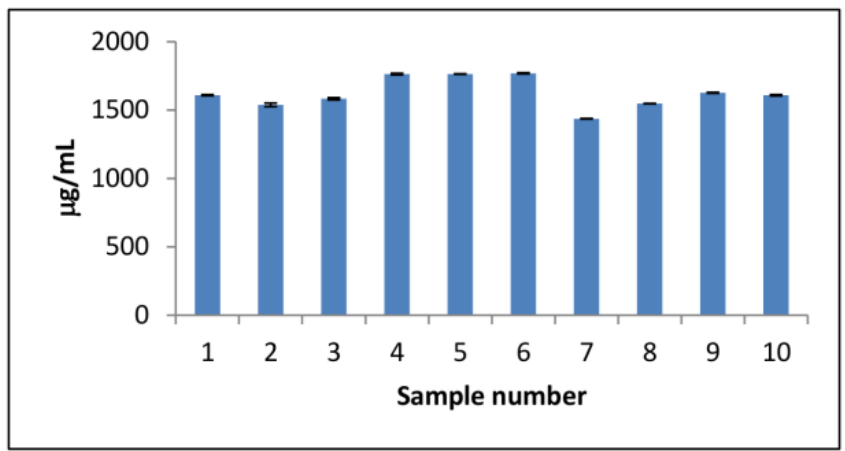

Figure 2d: Nitrate in BJ

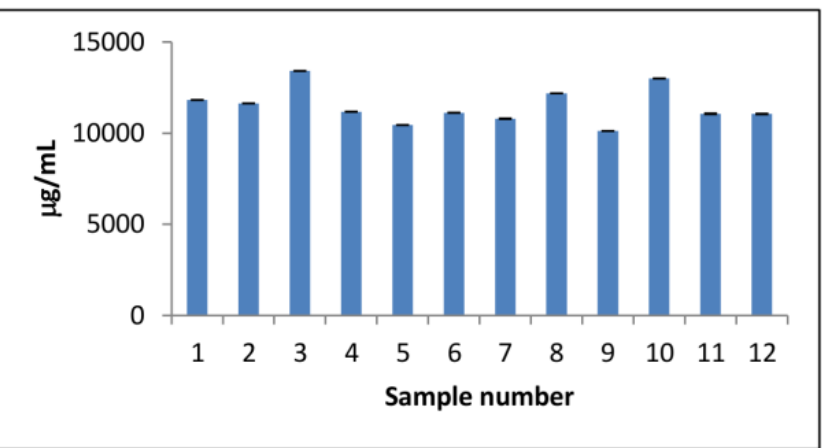

Figure 2e: Nitrate in CBJ

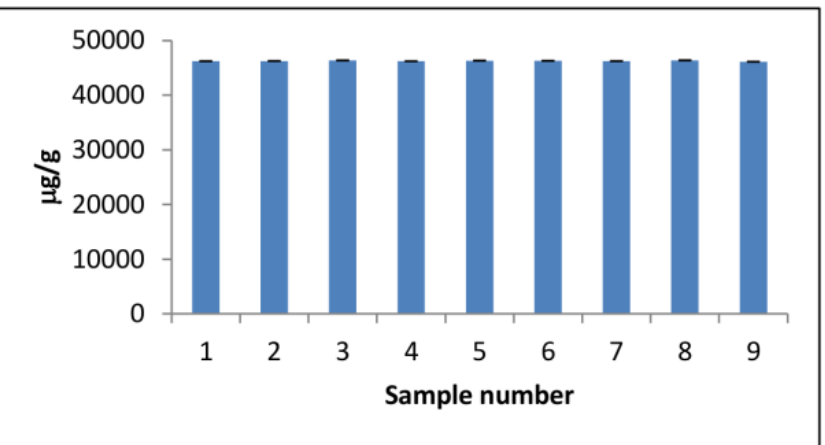

Figure 2f: Nitrate in SP

Figure 2: Shows the concentrations of $(a, d)$ nitrite and nitrate in BJ; (b, e) nitrite and nitrate in CBJ; and (c, f) nitrite and nitrate in SP across different batches. The sample numbers for nitrate and nitrate are matched for each supplement. Error bars represents standard error of mean.

hours and 72 hours respectively. The quality controls samples at three different concentration levels were divided into three sets. The first set was analyzed at 24 hours while thawing the other two sets, then $2^{\text {nd }}$ set of QC's were analyzed after 48 hours' time interval while thawing the third set and finally analyzing the third and final set after 72 hours gap. The \% variations in concentrations ranged between (-14.98-0.89). The results are within Food and Drug Administration (FDA) guideline for method validation $( \pm 15 \%)$, apart from one value for CBJ at a concentration of $25 \mu \mathrm{g} / \mathrm{mL}$ on the third freeze/thaw cycle. The results are shown in Table 4.

\section{Results and Discussion}

Nitrate and nitrite levels in SP, BJ and CBJ samples

Figure 2 shows that individual samples of $\mathrm{BJ}$ and $\mathrm{CBJ}$ would give different levels and greater variations, making SP an ideal candidate for supplementation studies when exact dosage is of importance. The one sample test statistics shows that the observed levels are significantly different from the labeled values for $\mathrm{BJ}(\mathrm{t}(9)=17.814, \mathrm{p}<0.001)$ and $\mathrm{BJ}$ concentrate $(\mathrm{t}(11)=25.522, \mathrm{p}<0.001)$. It is also notable that considerable inter-batch variations exist for the processed beetroot juices. In some cases these differences amount to some $25 \%$ for nitrate. In contrast, spinach powder was found to produce consistent levels of both nitrate and nitrite.

\section{Conclusions}

In the present study an accurate extraction method followed by ion chromatography with ultraviolet detection was presented for determination of nitrates and nitrites in BJ, CBJ and SP samples. Applying this assay, for beetroot preparations the nitrate levels differ 
Citation: Shah I, Petroczi A, James RA, Naughton DP (2013) Determination of Nitrate and Nitrite Content of Dietary Supplements Using lon Chromatography. J Anal Bioanal Tech S12: 003. doi:10.4172/2155-9872.S12-003

Page 6 of 7

from that described on the label and further variations were found between batches. Thus, this method of provision of nitrate and nitrite supplementation could be unreliable for use in supplementation studies if exact dosages are important. This study provides a novel approach to quantify nitrate and nitrite levels for supplementation studies.

\section{Competing Interests}

The authors declare that they have no competing interests.

\section{Authors' Contributions}

AP and DPN initiated the study. The method development was conducted by IS with contributions from RAJ and DPN. All authors contributed to the study design, preparation of the manuscript and have read and approved the final version.

\section{Acknowledgements}

The authors thank Michael Henson for screening the vegetable powders and juices and thank Julian Swinden for his technical help.

\section{References}

1. Avery AA (1999) Infantile methemoglobinemia: reexamining the role of drinking water nitrates. Environ Health Perspect 107: 583-586.

2. Bruning-Fann CS, Kaneene JB (1993) The effects of nitrate, nitrite and N-nitroso compounds on human health: a review. Vet Hum Toxicol 35: 521-538.

3. Kross BC, Ayebo AD, Fuortes LJ (1992) Methemoglobinemia: nitrate toxicity in rural America. Am Fam Physician 46: 183-188.

4. Jones AM, Poole DC (2005) Oxygen uptake dynamics: from muscle to mouth-an introduction to the symposium. Med Sci Sports Exerc 37: 1542-1550.

5. Lundberg JO, Weitzberg E (2010) NO-synthase independent NO generation in mammals. Biochem Biophys Res Commun 396: 39-45.

6. Dejam A, Hunter CJ, Schechter AN, Gladwin MT (2004) Emerging role of nitrite in human biology. Blood Cells Mol Dis 32: 423-429.

7. Hord NG, Tang Y, Bryan NS (2009) Food sources of nitrates and nitrites: the physiologic context for potential health benefits. Am J Clin Nutr 90: 1-10.

8. Milkowski A, Garg HK, Coughlin JR, Bryan NS (2010) Nutritional epidemiology in the context of nitric oxide biology: a risk-benefit evaluation for dietary nitrite and nitrate. Nitric Oxide 22: 110-119.

9. Visioli F, Bogani P, Grande S, Galli C (2005) Mediterranean food and health: building human evidence. J Physiol Pharmacol 56 Suppl 1: 37-49.

10. Brown GC (2000) Nitric oxide as a competitive inhibitor of oxygen consumption in the mitochondrial respiratory chain. Acta Physiol Scand 168: 667-674.

11. Davis JM, Murphy EA, Carmichael MD, Davis B (2009) Quercetin increases brain and muscle mitochondrial biogenesis and exercise tolerance. Am J Physiol Regul Integr Comp Physiol 296: R1071-R1077.

12. Rassaf T, Lauer T, Heiss C, Balzer J, Mangold S, et al. (2007) Nitric oxide synthase-derived plasma nitrite predicts exercise capacity. $\mathrm{Br} \mathrm{J}$ Sports Med 41: $669-673$

13. Davison R, Corbett J, Ansley L (2009) Influence of temperature and protocol on the calibration of the Computrainer electromagnetically-braked cycling ergometer. International SportMed Journal 10: 66-76.

14. Foster C, Green MA, Snyder AC, Thompson NN (1993) Physiological responses during simulated competition. Med Sci Sports Exerc 25: 877-882.

15. Sobko T, Marcus C, Govoni M, Kamiya S (2010) Dietary nitrate in Japanese traditional foods lowers diastolic blood pressure in healthy volunteers. Nitric Oxide 22: 136-140.

16. Bailey SJ, Fulford J, Vanhatalo A, Winyard PG, Blackwell JR, et al. (2010) Dietary nitrate supplementation enhances muscle contractile efficiency during knee-extensor exercise in humans. J Appl Physiol (1985) 109: 135-148.

17. Larsen FJ, Schiffer TA, Sahlin K, Ekblom B, Lundberg JO, et al. (2010) Improved mitochondrial efficiency in humans by dietary nitrate. Free Radic Biol Med 49: S116.
18. Larsen FJ, Weitzberg E, Lundberg JO, Ekblom B (2007) Effects of dietary nitrate on oxygen cost during exercise. Acta Physiol (Oxf) 191: 59-66.

19. Kapil V, Milsom AB, Okorie M, Maleki-Toyserkani S, Akram F, et al. (2010) Inorganic nitrate supplementation lowers blood pressure in humans: role for nitrite-derived NO. Hypertension 56: 274-281.

20. Lansley KE, Winyard PG, Bailey SJ, Vanhatalo A, Wilkerson DP, et al. (2011) Acute dietary nitrate supplementation improves cycling time trial performance. Med Sci Sports Exerc 43: 1125-1131.

21. Vanhatalo A, Bailey SJ, Blackwell JR, DiMenna FJ, Pavey TG, et al. (2010) Acute and chronic effects of dietary nitrate supplementation on blood pressure and the physiological responses to moderate-intensity and incremental exercise. Am J Physiol Regul Integr Comp Physiol 299: R1121-R1131.

22. Williams C, Nute MG, Broadbank L, Vinall S (1990) Influence of fluid intake on endurance running performance. A comparison between water, glucose and fructose solutions. Eur J Appl Physiol Occup Physiol 60: 112-119.

23. Jones AM, Wilkerson DP, Campbell IT (2004) Nitric oxide synthase inhibition with L-NAME reduces maximal oxygen uptake but not gas exchange threshold during incremental cycle exercise in man. J Physiol 560: 329-338.

24. Whipp BJ (2009) Point: the kinetics of oxygen uptake during muscular exercise do manifest time-delayed phases. J Appl Physiol (1985) 107: 1663-1665.

25. Walker R (1990) Nitrates, nitrites and N-nitrosocompounds: a review of the occurrence in food and diet and the toxicological implications. Food Addit Contam 7: 717-768.

26. Petróczi A, Naughton DP (2010) Potentially fatal new trend in performance enhancement: a cautionary note on nitrite. J Int Soc Sports Nutr 7: 25

27. European Commission (2006) Laying down methods of sampling and analysis for the official control of the levels of nitrates in certain foodstuffs. Official Journal of the European Communities No. L364.

28. Webb AJ, Patel N, Loukogeorgakis S, Okorie M, Aboud Z, et al. (2008) Acute blood pressure lowering, vasoprotective, and antiplatelet properties of dietary nitrate via bioconversion to nitrite. Hypertension 51: 784-790.

29. Muramoto $\mathrm{J}$ (1999) Comparison of nitrate content in leafy vegetables from organic and conventional farms in California. Center for Agroecology and Sustainable Food Systems, University of California, Santa Cruz.

30. Santamaria $P(2006)$ Nitrate in vegetables: toxicity, content, intake and EC regulation. J Sci Food Agric 86: 10-17.

31. Benjamin N, O'Driscoll F, Dougall H, Duncan C, Smith L, et al. (1994) Stomach NO synthesis. Nature 368: 502

32. Duncan C, Dougall H, Johnston P, Green S, Brogan R, et al. (1995) Chemical generation of nitric oxide in the mouth from the enterosalivary circulation of dietary nitrate. Nat Med 1: 546-551.

33. Zhang Z, Naughton D, Winyard PG, Benjamin N, Blake DR, et al. (1998) Generation of nitric oxide by a nitrite reductase activity of xanthine oxidase a potential pathway for nitric oxide formation in the absence of nitric oxide synthase activity. Biochem Biophys Res Commun 249: 767-772.

34. Cosby K, Partovi KS, Crawford JH, Patel RP, Reiter CD, et al. (2003) Nitrite reduction to nitric oxide by deoxyhemoglobin vasodilates the human circulation. Nat Med 9: 1498-1505

35. Lundberg JO, Carlström M, Larsen FJ, Weitzberg E (2011) Roles of dietary inorganic nitrate in cardiovascular health and disease. Cardiovasc Res 89: 525 532.

36. Bailey SJ, Winyard P, Vanhatalo A, Blackwell JR, Dimenna FJ, et al. (2009) Dietary nitrate supplementation reduces the $\mathrm{O} 2$ cost of low-intensity exercise and enhances tolerance to high-intensity exercise in humans. J Appl Physio (1985) 107: 1144-1155

37. Currell K, Jeukendrup AE (2008) Validity, reliability and sensitivity of measures of sporting performance. Sports Med 38: 297-316.

38. Ishibashi T, Yoshida J, Nishio M (2003) New methods to evaluate endothelia function: A search for a marker of nitric oxide (NO) in vivo: re-evaluation of NOx in plasma and red blood cells and a trial to detect nitrosothiols. J Pharmacol Sci 93: 409-416.

39. Boucher JL, Moali C, Tenu JP (1999) Nitric oxide biosynthesis, nitric oxide synthase inhibitors and arginase competition for L-arginine utilization. Cell Mol Life Sci 55: 1015-1028. 
Citation: Shah I, Petroczi A, James RA, Naughton DP (2013) Determination of Nitrate and Nitrite Content of Dietary Supplements Using lon Chromatography. J Anal Bioanal Tech S12: 003. doi:10.4172/2155-9872.S12-003

40. Kleinbongard P, Dejam A, Lauer T, Rassaf T, Schindler A, et al. (2003) Plasma nitrite reflects constitutive nitric oxide synthase activity in mammals. Free Radic Biol Med 35: 790-796.

41. Lauer T, Preik M, Rassaf T, Strauer BE, Deussen A, et al. (2001) Plasma nitrite rather than nitrate reflects regional endothelial nitric oxide synthase activity but lacks intrinsic vasodilator action. Proc Natl Acad Sci U S A 98: 12814-12819.

42. Laursen PB, Rhodes EC, Langill RH, McKenzie DC, Taunton JE (2002) Relationship of exercise test variables to cycling performance in an Ironman triathlon. Eur J Appl Physiol 87: 433-440.

43. Laursen PB, Shing CM, Tennant SC, Prentice CM, Jenkins DG (2003) A comparison of the cycling performance of cyclists and triathletes. J Sports Sci 21: $411-418$

44. Lansley KE, Winyard PG, Fulford J, Vanhatalo A, Bailey SJ, et al. (2011) Dietary nitrate supplementation reduces the $\mathrm{O} 2$ cost of walking and running: a placebo-controlled study. J Appl Physiol (1985) 110: 591-600.

45. Larsen FJ, Weitzberg E, Lundberg JO, Ekblom B (2010) Dietary nitrate reduces maximal oxygen consumption while maintaining work performance in maximal exercise. Free Radic Biol Med 48: 342-347.

46. Lauer T, Kleinbongard P, Kelm M (2002) Indexes of NO bioavailability in human blood. News Physiol Sci 17: 251-255.
47. Tang $Y$, Jiang $H$, Bryan NS (2011) Nitrite and nitrate: cardiovascular risk-benefit and metabolic effect. Curr Opin Lipidol 22: 11-15.

48. Remer T, Manz F (1995) Potential renal acid load of foods and its influence on urine $\mathrm{pH}$. J Am Diet Assoc 95: 791-797.

49. Helaleh MI, Korenaga T (2000) Ion chromatographic method for simultaneous determination of nitrate and nitrite in human saliva. J Chromatogr B Biomed Sci Appl 744: 433-437.

50. Siu DC, Henshall A (1998) lon chromatographic determination of nitrate and nitrite in meat products. J Chromatogr A 804: 157-160.

51. Everett SA, Dennis MF, Tozer GM, Prise VE, Wardman P, et al. (1995) Nitric oxide in biological fluids: analysis of nitrite and nitrate by high-performance ion chromatography. J Chromatogr A 706: 437-442.

52. Tamme T, Reinik M, Roasto M, Juhkam K, Tenno T, et al. (2006) Nitrates and nitrites in vegetables and vegetable-based products and their intakes by the Estonian population. Food Addit Contam 23: 355-361.

53. Akyüz M, Ata S (2009) Determination of low level nitrite and nitrate in biological food and environmental samples by gas chromatography-mass spectrometry and liquid chromatography with fluorescence detection. Talanta 79: 900-904.

54. Butt SB, Riaz M, Iqbal MZ (2001) Simultaneous determination of nitrite and nitrate by normal phase ion-pair liquid chromatography. Talanta 55: 789-797.
Citation: Shah I, Petroczi A, James RA, Naughton DP (2013) Determination of Nitrate and Nitrite Content of Dietary Supplements Using lon Chromatography. J Anal Bioanal Tech S12: 003. doi:10.4172/2155-9872.S12-003
Submit your next manuscript and get advantages of OMICS Group submissions

Unique features:

- User friendly/feasible website-translation of your paper to 50 world's leading languages

Audio Version of published paper

Digital articles to share and explore

Special features:

300 Open Access Journals

25,000 editorial team

21 days rapid review process

Quality and quick editorial, review and publication processing

Indexing at PubMed (partial), Scopus, EBSCO, Index Copernicus and Google Scholar etc

Sharing Option: Social Networking Enabled

- Authors, Reviewers and Editors rewarded with online Scientific Credits

Better discount for your subsequent articles

Submit your manuscript at: http://www.omicsonline.org/submission 